\title{
TEATRO-MATRIZ Y TEATRO LIMINAL: LA \\ LIMINALIDAD CONSTITUTIVA DEL ACONTECIMIENTO TEATRAL
}

\author{
Jorge Dubatti \\ Instituto de Artes del Espectáculo, Facultad de Filosofía y Letras, \\ Universidad de Buenos Aires \\ E-mail: jorgeadubatti@ hotmail.com
}

Nuestra intención es proponer dos nociones teóricas: teatro-matriz y liminalidad teatral, en tanto herramientas para un programa de investigación sobre la historia del teatro.Trabajamos en el marco de la Poética Comparada aplicada a una Historia del Teatro. ¿Qué historia del teatro escribir, qué corpus construir en tanto teatro? En nuestra exposición nos detendremos primero en la explicitación de estos conceptos y luego calibraremos los alcances de su aplicación para pensar los orígenes / las raíces del teatro.
Our intention is to propose two theoretical concepts: theater-matrix and theater liminality, as tools for a research program on the history of theater. We work within the framework of Comparative Poetics applied to a theater history. What theater history shall we write? What corpus shall we build in theater? In our discussion we will first look into these concepts and then calibrate the scope of their application in order to think about the origins/roots of theater.

Teatro. Liminalidad. Poética Comparada.

Theatre. Liminality. Comparative Poetics. 
El Concepto De Teatro-matriz, Una Precuela Teórica ${ }^{1}$

Compartamos desde el inicio una preocupación que surge del dictado de la materia Historia del Teatro Universal2: el problema de la pertinencia epistemológica de la categoría teatro para pensar procesos de larga duración, al menos desde el siglo VI a.C. en Grecia hasta el presente de una escena de globalización / planetarización. Estos procesos de milenios implican cambios en las visiones de mundo, las concepciones, las poéticas, las prácticas y las teorías: el teatro en la Antigüedad Grecolatina, en la Edad Media, en el Renacimiento, en los procesos de la Modernidad y hasta la Postmodernidad o Modernidad Crítica. ¿Podemos valernos de un único concepto de teatro? ¿Es adecuado el uso en común del término teatro? Venimos trabajando esta perspectiva hace años en la Universidad de Buenos Aires y, sólo en parte, la hemos expuesto en nuestra tesis doctoral sobre Eduardo Pavlovsky (2004), los tres tomos de nuestra Filosofía del Teatro (Dubatti, 2007, 2010, 2014a) y en El teatro de los muertos (2014b). Nuestro pensamiento sobre la necesidad de una redefinición de lo teatral como objeto de estudio es sincrónico con otros fenómenos del campo teatral de la Argentina y el mundo, en tanto en los últimos años se ha acrecentado la percepción de la problematicidad del teatro cuando se intenta responder: ¿qué entendemos por teatro? En la Post-dictadura argentina (período que se abre a partir de 1983) la definición teórica del teatro deja de tener una definición cerrada, desdibuja sus límites, se torna eminentemente abierta. El teatro deja de ser sólo una de las bellas artes, un edificio o un texto para ser representado por actores, como en las viejas definiciones de siglos pasados. Se problematiza. ${ }^{3} \mathrm{Y}$ es relevante señalar que esta nueva visión problemática del teatro implica nuevas dinámicas no sólo en la teoría, también en el comportamiento de los espectadores, en la legislación, en la programación de festivales, en el diseño de planes de estudio, en las políticas culturales, en la elaboración de los discursos críticos, etc.

Para enfrentar el interrogante de la problematicidad, proponemos el concepto de teatro -matriz: una estructura formal ontológica-histórica mayor, fundante, generadora, de la que se desprenden otras a lo largo de la historia y que las incluye a todas. El teatro-matriz sería constante, desde su surgimiento en la cultura hasta hoy, y de él se desprenderían prácticas, usos, concepciones diversas a través de la historia, que exigen en cada caso un estudio particular.

Para definir la idea de teatro-matriz necesitamos reconocer tres conceptos: teatralidad, teatro, transteatralización.

El concepto de teatralidad es de raíz antropológica. Desde una Antropología del Teatro ${ }^{4}$, la teatralidad es una condición de lo humano que consiste en la capacidad del hombre de organizar la mirada del otro, de producir una óptica política o una política de la mirada. ${ }^{5} \mathrm{EI}$ mundo humano se sostiene en una red de mirada. Una red de mirada (de lo que debe y no debe verse, de lo que puede y no puede verse) genera acción social y sostiene el poder,

\footnotetext{
1 Conferencia pronunciada en el Programa de Pós-Graduação em Artes Cênicas, Universidade Federal do Rio Grande do Sul, 31 de mayo de 2016.

2 Carrera de Artes, Orientación en Artes Combinadas, Facultad de Filosofía y Letras, UBA.

${ }^{3}$ Hemos desarrollado el tema en Dubatti, 2015a.

${ }^{4}$ Antropología del Teatro: disciplina científica de la Teatrología que estudia los fenómenos teatrales por su relación con la teatralidad humana, es decir, con la teatralidad como atributo sin el cual la Humanidad sería inconcebible.

5 Partimos para esta formulación de una apropiación, desde una perspectiva antropológica, de la propuesta de Gustavo Geirola, 2000, de base psicoanalítica.
} 
el mercado, la totalidad de las prácticas sociales. Desde una perspectiva antropológica, así como la especie se define en el Homo Sapiens (el Hombre que sabe), el Homo Faber (el Hombre que hace) y el Homo Ludens (el Hombre que juega), se reconoce un Homo Theatralis, una "Humanidad Teatral". La teatralidad es inseparable de lo humano y acompaña al hombre desde sus orígenes. Incluso podemos hablar de una teatralidad preconsciente del infante, por ejemplo, en las dinámicas del llanto. La teatralidad (organizar la mirada del otro, dejarse organizar la propia mirada por la acción del otro, establecer un diálogo en ese juego de miradas) está presente en la esfera completa de las prácticas humanas en sociedad: la organización familiar, la cívica, el comercio, el rito, el deporte, la sexualidad, la construcción de género, la violencia legitimada, la educación, y otras innumerables formas de lo que podemos llamar la teatralidad social. También está presente en el teatro, ya que tardíamente éste se apropia de la teatralidad para darle un uso específico.

El teatro en sentido genérico y abarcador, el teatro-matriz, sería resultado de un nuevo uso, tardío respecto de los anteriores, de la teatralidad humana, y se emparenta, por vía antropológica, con la gran familia de prácticas originadas en la teatralidad social. El teatro propone un uso singular de la organización de la mirada, que exige: reunión, poíesis corporal y expectación. La Filosofía del Teatro define ese uso como un acontecimiento en el que artistas, técnicos y espectadores se reúnen de cuerpo presente (el convivio) para expectar (recordemos que el término teatro, en griego, théatron, podría traducirse "mirador", "observatorio") la aparición y configuración de una construcción de naturaleza metafórica, mun- do paralelo al mundo, con sus propias reglas, en el cuerpo de los actores (Aristóteles, en su Poética, llama a esa construcción poíesis y de ese término proviene la palabra poesía).

Hay otra vuelta de tuerca, desde hace siglos, acentuada en el mundo contemporáneo: la transteatralización. Llamamos transteatralización a la exacerbación y sofisticación del dominio de la teatralidad -fenómeno extendido a todo el orden social- a través del control y empleo de estrategias teatrales pero, en la mayoría de los casos, para que no se perciban como tales. Abonada por el auge de la mediaticidad y la digitalización, se produce una proyección del teatro sobre la teatralidad antropológica como resultado de una dinámica invertida: como en el dominio de la política de la mirada se sostienen el poder, el mercado y la vida social desde los medios, para optimizar y cultivar el control de la teatralidad se recurre a las estrategias y procedimientos del teatro. Las múltiples prácticas de la teatralidad social se enriquecen con los saberes y estrategias del teatro. Políticos, periodistas, pastores, abogados, gerentes de empresas, comerciantes, docentes, entre otros, realizan cada vez más cursos y entrenamientos de teatro para valerse de esos saberes y destrezas al servicio de un mayor dominio de la teatralidad social en sus campos específicos.

Un ejemplo: organizar la mirada de las vastas audiencias implica construir opinión pública, ganar o perder elecciones, vender más o menos productos. . La Retórica investiga ancestralmente las formas de dominar la organización de la mirada del otro (Pricco, 2015). La publicidad puede ser estudiada desde los mecanismos de la transteatralización. En la transteatralización el teatro borra su carácter poiético. Frente al auge social de la 
transteatralización -término clave para la comprensión del mundo contemporáneo-, el teatro poiético dialoga con esa tendencia: plantea fricciones, reacciones, resistencias o filiaciones, para poner en evidencia su relación o diferencia con la transteatralización ${ }^{6}$.

De esta manera, definimos teatro, en un sentido genérico e incluyente: teatro-matriz, a todos los acontecimientos en los que se reconoce la presencia conjunta y combinada de convivio, poesía corporal ${ }^{7}$ y expectación. El teatro puede incluir elementos tecnológicos (como en la llamada escena neotecnológica8, cada vez más extendida en Buenos Aires), pero no puede renunciar al convivio, a la presencia aurática corporal productora de poíesis. Oponemos a convivio, entonces, tecnovivio, paradigma existencial de la vida cotidiana que permite, gracias a recursos tecnológicos, establecer un vínculo desterritorializado (sin reunión territorial) que permite la sustracción del cuerpo presente. Las prácticas artísticas que se fundamentan en la impresión o la transmisión digital y satelital (la literatura impresa, el cine, la televisión, el video, etc.), son prácticas tecnoviviales. En el convivio territorialidad y cuerpo presente son condiciones sine qua non. El teatro-matriz se funda en un acontecimiento de convivio + poíesis + expectación: es una matriz-acontecimiento.

¿Por qué perseverar en el término ancestral "teatro", y no recurrir a otros más cercanos, como "artes escénicas"? Porque etimológicamente el término "théatron" -lugar para ver, mirador, observatorio- reenvía a su manera a las nociones de lugar (territorialidad) al que acudir y donde reunirse (convivio), para mirar (percibir, pensar, inteligir, en raíz compartida con el término theoría), y especialmente para mirar, con un sentido de transitividad, algo que aparece (Naugrette, 2004). El término "arte escénica" no implica necesariamente ni territorialidad compartida ni reunión convivial (por ejemplo, son artes escénicas las aguas danzantes, los espectáculos con hologramas y autómatas, determinados usos de las artes visuales), exige la distinción entre artes escénicas conviviales y no conviviales. Nuestra propuesta reivindica un valor teórico de la palabra teatro, desde la contemporaneidad hacia el pasado del derrotero teatral, más allá de los usos históricos que la palabra tuvo en particular en cada época y contexto. Invocamos un doble movimiento que persigue un equilibrio de diacronía/ sincronia/anacronía: del origen etimológico ancestral hacia el presente, de la contemporaneidad hacia el pretérito con una nueva carga semántica. Teatro-matriz, en tanto genérico, vale para pensar una estructura común (y a la vez diversa) presente en el aedo de la Antigua Grecia, en el drama litúrgico medieval, el teatro de boulevard y el teatro realista, la performance y el happening.

Todo lo que esa matriz toma, lo absorbe / transforma en teatro (Tellas, 2010), opera como una modelización de segundo grado (Lotman, 1988, 1996): el teatro per-forma (Schechner, 2012), da forma a través de la matriz de acontecimiento. En forma complementaria, en nuestro Filosofía del Teatro II y III (2010 y 2014a), hemos expuesto la primacía de la ley de poietización (todo se transforma

\footnotetext{
${ }^{6}$ Véase al respecto nuestro "Teatralidad, teatro, transteatralización: notas sobre teatro argentino actual (y en particular sobre La máquina idiota de Ricardo Bartís)" (2014c).

${ }^{7}$ Cuando hablamos de poíesis corporal, no nos referimos a estética de la prosaica corporal. Para diferenciar poética y prosaica, véase Katya Mandoki (2006a, 2006b y 2007).

8 Llamamos así a la escena de Buenos Aires que incluye en su poética recursos de los nuevos avances tecnológicos: digitalización, redes ópticas, streaming, proyecciones, escenografía computarizada, etc. Véase Sassone, 2005.
} 
en poíesis) por sobre la ley de semiotización. Todo se transforma en teatro: la matriz es así vastamente inclusiva: permite combinatorias internas de esos componentes, variables en estructura (organización interna jerárquica de los componentes), trabajo (formas de producción, técnicas y métodos, uso de materiales finalmente ausentes en la estructura) y concepción (cómo piensa la poética su relación con el universo: la sociedad, la política, los sagrado, la naturaleza, el lenguaje, el sexo y el género, etc) ${ }^{9}$. Esto implica una (re)ampliación del concepto de teatro, que pasa a incluir bajo ese nombre fenómenos de gran diversidad a través de las épocas (teatro griego, teatro latino, teatro cristiano, teatro renacentista, etc.). Por la diversidad de sus posibles inclusiones, el teatro-matriz se propone de esta manera como un genérico implícito que per-forma los materiales que convoca o absorbe y transforma: podemos proponer la fórmula

teatro + de $[\ldots]$

Es decir: teatro + de [prosa, danza, movimiento, muñecos, mimo, papel, poesía, relato, etc.], o también teatro + de [la cultura griega, la latinidad, la cristiandad, etc.].

A partir de esta (re)ampliación del registro genérico, del teatro a teatro-matriz, se considera teatro tanto a las formas convencionalizadas (teatro de prosa o en verso representado por actores en salas especialmente diseñadas) como al teatro de mimo, de títeres y objetos, de nuevo circo, de papel (a la manera japonesa, el kamishibai), de impro (improvisación), de danza, de movimiento, de sombras, del re- lato (o narración oral), de calle, de alturas o las infinitas formas del teatro musical, el stand up, teatro neotecnológico (con aplicaciones de internet, proyecciones, hologramas, autómatas, etc.), entre otros. Toda aquella práctica en la que se verifique, de manera completa o fragmentaria, continua o discontinua, la matriz de acontecimiento convivio + poíesis corporal + expectación. La matriz es tan abarcadora que las combinaciones internas resultan ilimitadas.

También se incluyen los fenómenos que enseguida definiremos como teatro de la liminalidad, en sus distintas formas: performing arts, teatro performático y happening, serata (las veladas italianas del futurismo), varieté, music hall, circo, intervenciones urbanas, acciones políticas como los escraches, las instalaciones con presencias corporales vivientes, teatro postdramático, teatro invisible (Augusto Boal), teatro ambiental, teatro rásico, teatro en los transportes públicos, biodrama, etc.

Ya no se usa, entonces, la palabra teatro como en el pasado, hoy está cargada de más vastas referencias. ¿Qué corpus incluiría una historia del teatro en la Argentina? Tanto los recitales de Madonna como las obras de Eduardo Pavlovsky y el Desfile del Bicentenario del 25 de mayo de 2010 organizado en Buenos Aires por el grupo Fuerza bruta, las instalaciones con poíesis corporal, la narración oral y la magia. Una gran conquista epistemológica: sin duda un mayor acercamiento a la realidad del teatro y a la complejidad de sus vínculos fronterizos e intercambios con el resto del mundo. El teatro está hecho de mundo, y el mundo está hecho de teatro. La definición de teatro, parafraseando a Beckett, ha dejado entrar el caos al mismo tiempo que ha

\footnotetext{
${ }_{9}$ Para el desarrollo de una teoría de la poética como estructura + trabajo + concepción, véanse Dubatti, 2009 y 2010.
} 
buscado diseñar un concepto inclusivo de las formas teatrales en los procesos de larga duración. El teatro-matriz involucra el amplio espectro entre el prototipo moderno ${ }^{10}$ (fuerza centrípeta) y la liminalidad (fuerza centrífuga hacia el no-teatro).

Como adelantamos antes, esta nueva visión (re)ampliada del teatro implica nuevas dinámicas en el comportamiento de los espectadores, en la legislación, en la programación de festivales, en el diseño de planes de estudio, en las políticas culturales, etc. El concepto de teatro se complejiza en todos los planos de la actividad, y esto acarrea necesarios cambios en las dinámicas de cada actividad.

Este nuevo uso del concepto teatro-matriz no sólo vale para pensar el presente, sino también la historia. En este sentido advertimos en la idea de teatro-matriz un doble valor temporal: es un concepto de formulación contemporánea para pensar fenómenos contemporáneos; es un concepto de formulación contemporánea para pensar fenómenos antiquísimos. Por eso nos gusta pensar el concepto de teatro-matriz como una precuela teórica: un concepto formulado después para nombrar lo que estaba -mucho- antes.

Por eso no hablamos de visión "ampliada" (o, como es frecuente oír hoy, "extendida") del teatro, sino (re)ampliada: sobre una visión más amplia en los primeros tiempos, la Modernidad fue operando un estrechamiento reduccionista que terminó excluyendo de la noción de teatro una vasta masa de fenómenos teatrales. (Durante muchos años, por ejemplo, por influencia de esa reducción teórica moderna, se dijo que el teatro había desaparecido en la Edad Media.) ${ }^{11}$ Las nuevas teorizaciones, como ésta de teatro-matriz, permiten incluir en tanto teatro un sistema de expresiones mucho más vasto y complejo.

El Doble Concepto De Liminalidad En EI Teatro

Vayamos, entonces, al segundo concepto propuesto: liminalidad teatral. Recurrimos inicialmente al concepto de liminalidad para pensar fenómenos del teatro actual o del pasado reciente que no se encuadran en el marco de un teatro convencionalizado/reducido por la Modernidad como teatro de representación de una historia (con personajes, ficción) o teatro dramático. Recordemos al respecto las teorizaciones de Hegel, Szondi, Staiger, Kaiser, sobre el concepto de drama. Dice Kaiser: "Tenemos ante nosotros un drama cuando, en un espacio determinado, unos 'actores' representan un acontecimiento. Lo que de este modo se representa está determinado por los tres mismos elementos fundamentales que determinan el mundo narrado por el poeta épico: el acontecimiento, el espacio y el personaje" (1968, p. 489).

Los fenómenos de liminalidad son aquellos que nos llevan a preguntarnos: ¿es esto teatro? Poseen las características relevantes del teatro-matriz (convivio, poíesis corporal, expectación), pero a la vez incluyen otras características que, en las clasificaciones aceptadas -el concepto canónico de teatro para la

\footnotetext{
10 Nos referimos como prototipo moderno a la idea de drama absoluto y su representación. Retomaremos enseguida este tema.

11 Véase al respecto nuestro estudio sobre el teatro medieval (2013c).
} 
Modernidad: lo dramático-, no corresponden al teatro. ${ }^{12}$ Retomando la distinción de Prieto Stambaugh (2009): no el teatro en fuerza centrípeta hacia el prototipo moderno (el drama, cuya expresión extrema sería la poética que Szondi llama "drama absoluto"), sino en fuerza centrífuga hacia el no-teatro. Es decir, el teatro en función hacia el no-teatro, o al revés: el noteatro en función hacia el teatro. ${ }^{13}$

Pero, al margen de esas nuevas expresiones, consideramos que el concepto de liminalidad sirve además para pensar aspectos inmanentes al acontecimiento del teatro-matriz (que incluye, por supuesto, las manifestaciones del teatro convencionalizado de representación o teatro dramático). Es decir: la liminalidad es también parte del acontecimiento teatral en su definición genérico. No hay teatro sin liminalidad. Llamamos liminalidad a la tensión de campos ontológicos diversos en el acontecimiento teatral: arte / vida; ficción / no-ficción; cuerpo natural / cuerpo poético (en todos los niveles de ese contraste: enunciado / enunciación, constructo poético / construcción poética); representación / no-representación; presencia / ausencia; teatro / otras artes; teatralidad social / teatralidad poética; convivio / tecnovivio, etc. En su plano más abarcador, dramático / no-dramático. Como se desprende de esta definición general, no seguimos el concepto de liminalidad tal como lo señala Ileana Diéguez $(2007,2014)$ en su Escenarios liminales -a partir de Victor Turner-, sino que, partiendo de su reflexión, basándonos en sus investigaciones instauradoras, le damos otra dimensión más amplia y abarcadora, ligada a la manifestación de liminalidad en el teatro -matriz.

Venimos sosteniendo en diversas investigaciones que esa tensión de campos ontológicos es uno de los atractivos más relevantes del acontecimiento teatral. Por eso hemos definido el teatro como "observatorio ontológico" en nuestra Filosofía del Teatro. ${ }^{14}$

El concepto de liminalidad, tal como lo usamos, propone que en el teatro hay fenómenos de fronteras, en el sentido amplio en que puede reconocerse la idea de lo fronterizo ${ }^{15}$, incluso en términos opuestos: límite o lugar de pasaje, separación o conexión, zona compartida de intercambio o combinación, fusión o conflicto, tránsito, circulación y cruce, puente y prohibición, permanencia o intermitencia, zona de mezcla, hibridez, transfiguración, periferia, lo ex-céntrico, el dominio borroso o desdelimitación, la interrelacional, lo intermedial, incluidos lo inter-fronterizo y lo trans-fronterizo, etc. De esta manera sintetizamos en una doble fórmula:

\footnotetext{
12 Entre otros, los temas a los que dedicamos el volumen colectivo sobre el tema Dramático y no-dramático. Poéticas de liminalidad en el teatro, encargo de Editorial Paso de Gato, México (Dubatti, 2016a): café-concert, teatro de la poesía, nuevo teatro documental, performance, instalación, museos, teatro de estados, desfiles, teatro del tango, teatro foro y "espect-actor" (Boal), intervención urbana, teatro aplicado, teatro musical, teatro y rito, teatro y psicodrama, teatro comunitario, teatro del relato, magia, biodrama, teatro site-specific, teatro físico, clown, teatro de las artes audiovisuales, teatro ciego, catch, stand-up, kamishibai, teatro acrobático, teatro-danza, teatro de títeres y objetos, teatro del movimiento, teatro leído, teatro semimontado, formas teatrales intermediales o multimediales, etc.

13 Casos: la lectura en voz alta de textos no teatrales, los desfiles de modas.

${ }^{14} \mathrm{Al}$ respecto, véase nuestro "El teatro como observatorio ontológico en las poéticas de la Postdictadura: concepciones y pluralismo" (2016b).

15 Son valiosas al respecto las reflexiones de Beatriz Rizk (2001, 2007), Pompeyo Audivert (2014) o la propuesta de un Teatro Fronterizo en la producción de José Sanchís Sinisterra.
} 
teatro $>$ drama

o también

teatro: dramático + no-dramático

Proponemos no identificar drama con teatro, éste es más amplio que aquel; por otra parte, teatro sería la suma de dramático y nodramático.

Creemos que la idea de liminalidad tiene entonces un doble valor: 1) es una herramienta superadora de las categorías taxonómicas modernas que proponían una clasificación racionalista y excluyente (sólo es teatro el teatro dramático, o sus variantes más o menos canónicas y aproximadas), poco válida para pensar los fenómenos concretos de la praxis (contra los sistemas cerrados de pensamiento, la idea de liminalidad incluye muchos fenómenos teatrales no prototípicos ni canónicos); 2) permite descubrir fronteras internas en el acontecimiento teatral canónico, incluso en el drama absoluto. De esta manera empleamos el concepto de liminalidad en dos dimensiones diversas, una primera más restrictiva y una segunda más general o abarcadora: la oposición teatro convencionalizado / teatro liminal; la liminalidad interna al acontecimiento teatral en sí, interna al teatro-matriz, que descubre la liminalidad tanto en las formas del teatro convencionalizado como las del teatro liminal.

Sostenemos que, en la historia del teatro occidental, es la vanguardia histórica -fundamentalmente futurismo, dadaísmo, surrealismo- la que introduce en el teatro una auténtica revolución en todos los niveles (poético, político, histórico, conceptual, etc.), dentro de la que el valor de la liminalidad es relevante, tanto en las prácticas como en las teorías. Si en la vanguardia se busca la fusión del arte con la vida, en la postvanguardia -como reelaboración del "fracaso" y del "triunfo" de la vanguardia- se trabaja con la tensión del arte con la vida (Dubatti, 2013a). ${ }^{16}$ Por otra parte, por la potencia de su gesto revolucionario, la vanguardia histórica es una "bisagra" hacia adelante y hacia atrás en la historia teatral: a) hacia adelante, a manera de un descomunal "big bang", la vanguardia genera la postvanguardia -con manifestaciones hasta hoy-; b) hacia atrás, la vanguardia invita a recuperar la historia teatral despreciada por la Modernidad, y propone redescubrir la liminalidad en el pasado.

Un ejemplo de la fuerza de la vanguardia en la construcción de un campo procedimental y reflexivo sobre la liminalidad puede hallarse en Antonin Artaud: por ejemplo, en su teoría del teatro como "acto" en uno de los manifiestos del Théâtre Alfred Jarry ("A partir del Théâtre Alfred Jarry, el teatro ya no será más esta cosa encerrada, clausurada en el espacio estrecho del escenario, sino que tendrá por objetivo transformarse verdaderamente en un acto, sometido a todas las demandas y a todas las deformaciones de las circunstancias y donde el azar encuentre sus derechos", 1970, tomo II, p. 34); b) sus referencias al teatro pre-moderno, y específicamente al teatro de la Antigüedad Grecolatina, en El teatro y su doble.

El concepto de liminalidad es muy productivo, porque: a) nos permite reconocer una cantidad ilimitada de fenómenos de tensión liminal en las prácticas artísticas y no-artísticas del presente; b) nos permite reconocer una

\footnotetext{
${ }^{16}$ Véase nuestro estudio sobre la dramaturgia de Alejandro Finzi (2015c).
} 
cantidad ilimitada de fenómenos de tensión liminal en el pasado, incluso el pasado más remoto. Por ejemplo: las tensiones entre rito/ teatro, las prácticas de los mimos grecolatinos y los histriones medievales, las tensiones entre épica / drama, etc. En este sentido advertimos en la idea de liminalidad un doble valor temporal, como antes señalamos para el teatro-matriz: es un concepto de formulación contemporánea para pensar fenómenos contemporáneos; es un concepto de formulación contemporánea para pensar fenómenos antiquísimos. Por eso el concepto de liminalidad responde también en tanto precuela teórica (un concepto formulado después para nombrar lo que estaba -mucho- antes). Parecería que necesitamos producir precuelas teóricas porque el teatro va por delante del pensamiento y siempre pensamos el teatro en pasado, no en presente: hace falta tiempo para pensar lo que se hace en el acontecimiento teatral.

\section{La Liminalidad}

\section{En El Teatro-matriz y En El Teatro Liminal}

Detengámonos, primero, en la dimensión más abarcadora de la liminalidad, aquella interna al acontecimiento teatral en sí, la liminalidad en el teatro-matriz. Sin pretender ser exhaustivos, podemos reconocer la liminalidad dentro del acontecimiento del teatro-matriz en diversos niveles destacables:

I: las tensiones entre representación, presentación y sentación. En nuestro Filosofía del Teatro $(2010,2014 a)$ hemos destacado la naturaleza triádica del acontecimiento teatral: re -pre-sentación. Para que haya representación, debe haber presentación y sentación. Como señala la Filosofía del Teatro, los fundamentos del acontecimiento teatral: el convivio y la poíesis corporal, ya son en sí mismos un espacio liminal entre el arte y la vida. En el espesor ontológico de la poíesis teatral confluyen materiales heterogéneos: lo real y la realidad, el proceso de trabajo y el objeto construido por el trabajo (la doble dimensión de la construcción poiética), lo pre-semiótico y lo semiótico, la presencia y la ausencia.

II: el cuerpo del actor es el espacio por excelencia de observación de la liminalidad, el cuerpo del actor es un auténtico "observatorio ontológico". En él observamos al menos acontecer tres cuerpos: el cuerpo natural/social, el cuerpo afectado, el cuerpo poético (Dubatti, 2014a). Incluso en el teatro convencionalizado más radicalmente purista $u$ ortodoxo (el drama absoluto), estas tres dimensiones nunca se ausentan y el espectador puede realizar al mismo tiempo observaciones sobre los tres planos ontológicos: ver vivir al actor, verlo trabajar/representar, ver lo representado en su cuerpo.

III: otro componente fundamental en la definición de la liminalidad es el espectador en su presencia convivial. Es el convivio de actores-técnicos-espectadores lo que determina la base del acontecimiento teatral y condiciona la poíesis, que no sólo acontece en el cuerpo del actor. El espectador interactúa con el actor y configura la poíesis con sus intervenciones, sea a través del silencio, la risa o el llanto, los aplausos o el rechazo. Por eso hablamos de una poíesis productiva (la del actor), otra receptiva (la de los espectadores) y una tercera convivial (que se genera en la dinámica imprevisible del convivio) (Dubatti, 2010).

IV: la tensión entre la teatralidad de las prácticas sociales y el uso poiético de la teatralidad en el teatro: si bien poseen una diferencia 
específica, que hemos señalado arriba, comparten un origen común, la base de la teatralidad como atributo antropológico (Homo Theatralis). En algunos casos la poíesis teatral, a partir de la mímesis, absorbe y reelabora en metáfora la observación de la teatralidad social, poniéndola en evidencia, muchas veces discutiéndola o desenmascarándola como teatralidad. ${ }^{17}$

V: la tensión entre presencia y ausencia se advierte además en el plano rítmico, musical, de intensidades y velocidades con que se articula lo representacional (el "teatro de estados" según Bartís). La materialidad del signo reenvía al cuerpo presente del actor, a su campo proposicional poético vital (hay una poética del actor anterior a la poética del espectáculo, que diferencia a Alejandro Urdapilleta de Alfredo Alcón), y también a su trabajo (hay aspectos del trabajo que no son "representacionales" en determinadas poéticas: el personaje yace muerto en escena y el actor se levanta y sale de escena caminando, zonas liminales de "interrupción" de la representación: el espectador sabe que no debe pensar que el personaje resucitó...).

En la totalidad de estos niveles juega la tensión entre dramático y no-dramático. Pero además las distintas poéticas en la historia del teatro realizan a su vez combinaciones de dramático y no-dramático según diversidad de procedimientos, convenciones, concepciones, formas de trabajo, etc. Por ejemplo: el uso combinatorio de estos procedimientos varía si se confronta el teatralismo de la commedia dell'arte en el siglo XVI con la ilusión de contigüidad realista del drama moderno en el siglo XIX.
Podemos concluir que, por la naturaleza liminal, híbrida, de la articulación entre arte y vida en el teatro, dramático y no-dramático se implican más allá de la voluntad de los artistas, es decir, autopoiéticamente (Dubatti, 2010).

Veamos ahora, resumidamente, formas más restrictivas y específicas de liminalidad que permiten hablar específicamente de un teatro liminal, es decir, el teatro fronterizo con el no-teatro, diverso al teatro convencionalizado por la Modernidad, centrémonos en cinco ejes (revelación del convivio, convención consciente, hibridez, no-ficción, capacidad de absorción de materiales no teatrales) de oposición con el drama absoluto:

- si el drama absoluto propone un teatro centrado en la autosuficiencia del mundo representado, que tiende a borrar los mecanismos de la enunciación convivial y aurática, el teatro liminal pone el acento en la presencia del espectador, en las dinámicas del convivio, en la ruptura de la cuarta pared. Ejemplos: el café-concert, el clown, el teatro épico, el stand -up, el teatro foro y "espect-actor" (Boal).

- si el drama absoluto es ilusionista, el teatro liminal es teatralista (John Gassner, 1963), rompe la ilusión poniendo en evidencia el procedimiento de construcción, la convención consciente, por ejemplo a través de la autorreferencia o lo metateatral.

- si el drama absoluto propone un teatro centrado eminentemente en la palabra, el teatro liminal pone el acento en la ausencia de palabra, en el cruce de la palabra con el movimiento, la música, la plástica, los objetos, con otras disciplinas. Ejemplos: el teatro-danza, el teatro musical, la titiritesca, el teatro físico, el happening, la instalación, teatro del relato,

\footnotetext{
17 Un ejemplo es el entrenamiento teatral del mafioso Arturo Ui en la pieza de Bertolt Brecht.
} 
magia, teatro de las artes audiovisuales, teatro ciego, kamishibai, teatro acrobático, teatro del movimiento, teatro leído, teatro semimontado, formas teatrales intermediales o multimediales.

- si el drama absoluto propone un teatro que cuenta una historia ficcional, el teatro liminal mezcla ficción y no-ficción, borra los límites entre el teatro y la vida, desdibuja el salto ontológico que la poíesis marca respecto de la realidad cotidiana. Ejemplo: el biodrama, el nuevo teatro documental, la performance, la magia, el teatro-fiesta, el teatro-rito.

- si el drama absoluto trabaja con la estructura teatral canónica para contar una historia, el teatro liminal absorbe, transforma en la matriz del teatro cualquier material no teatral (documentos, tratados científicos y filosóficos, manuales, novelas, poesía, etc.).

\section{Dramático}

y No-dramático: Hacia Una Nueva Historia Del Teatro Desde Los Orígenes/Desde Las Raíces

Tanto la idea de teatro-matriz como la de omnipresencia de la liminalidad ponen en jaque el carácter "absoluto" del drama señalado por Peter Szondi en la historia del teatro moderno. A partir de la lectura de Hegel y Staiger, Szondi propone que "el drama es una entidad absoluta" (1994, p. 18). Lo afirma en relación al espectador: "La relación entre espectador y drama conoce sólo la separación absoluta y la identidad absoluta, pero no la injerencia del espectador ni la interpelación a éste desde el drama" (ibídem, p. 19). También en relación al actor: "El arte de la interpretación también está llamado a subrayar el carácter ab- soluto del drama. Bajo ningún concepto debe apreciarse la relación existente entre el actor y el papel que desempeñe; antes bien, actor y figura han de fundirse en un solo personaje dramático" (ibídem, p. 20). Sin embargo, en el acontecimiento del teatro-matriz, lo dramático y lo no-dramático conviven, se cruzan, se necesitan mutuamente. Uno no puede anular al otro, sencillamente encuentran y asumen formas de relacionarse diversas.

Si bien explícitamente Aristóteles no parece hacer referencia a lo liminal, su idea de drama (acción) es mucho más lábil y amplia que la de Hegel, Staiger o Szondi como para reconocer implícitamente aspectos de la liminalidad (por ejemplo entre enunciación y enunciado, mundo representado y representación, presencia y ausencia).

Incluso en Hegel, la idea de tensión entre realidad y apariencia está presente en su definición del drama: "[El drama] expone una acción completa como realizándose ante nuestra vista; y ésta, al propio tiempo, parece emanar de las pasiones y de la voluntad íntima de los personajes que la desarrollan" (2008, tomo II, p. 489). Pongamos el acento en el "como realizándose" y en el "parece".

Hasta en las formas más cerradas del drama absoluto, el drama se combina en el acontecimiento con los elementos no-dramáticos. En consecuencia, para la consideración del drama en la historia, no debemos partir de la idea de drama absoluto del teatro moderno hacia atrás y hacia adelante, no debemos hacer teleología del drama moderno y salir a buscar desde el siglo XIX antecedentes en la historia y procesos de configuración. 
Lo dramático estaría presente en el origen mismo del teatro en tanto medio imaginista (Rozik, 2014a), y lo estaría siempre en tensión liminal con lo no-dramático. Dice Rozik: "Sostengo que el teatro es un medio imaginista (imaginistic medium) específico, es decir, un método de representación o, más bien, un instrumento de pensamiento y comunicación, y como tal sus raíces yacen en la espontánea facultad del cerebro humano de crear imágenes y utilizarlas en procesos de pensamiento" (2014ª , p.13). Rozik distingue orígenes y raíces del teatro: identifica el primer término con la idea de comienzos; el segundo, con la de principio. En consecuencia, desde una teoría de las raíces del teatro, debemos comprender como dramática toda práctica corporal imaginística, completa o fragmentaria, figurativa o abstracta, a través de la creación de poíesis corporal.

Proponemos entonces no poner como centro categorial lo moderno como organizador de nuestro discurso histórico y, en consecuencia, no articular los procesos históricos como lo hace Lehmann (2013): teatro pre-dramático, dramático y post-dramático. Proponemos poner el acento en una historia que desde los orígenes ancestrales observe lo dramático tensionado con lo no-dramático, una historia de las relaciones y combinaciones entre drama y liminalidad. Hablamos de historia desde los orígenes, si buscamos comprender los primeros períodos del proceso histórico; pero también hablamos de historia desde las raíces, según el término de Rozik, es decir, desde el principio fundante de lo dramático, el medio imaginístico.
La permanente liminalidad constituyente del acontecimiento teatral nos permite cuestionar la idea contemporánea de "retorno a lo real" y el concepto de "teatro expandido" (Sánchez, 2013). En realidad lo real siempre estuvo presente en el estatus de liminalidad del acontecimiento del teatro-matriz. Ya señalamos arriba que deberíamos hablar de un teatro (re) ampliado. Agregamos ahora: desplacemos el concepto de "teatro expandido" por el de teatro-matriz, proyectándolo -en tanto precuela teórica- como presencia a través de los siglos, desde los orígenes hasta el presente.

\section{Antiguo y Las Poéticas De La Liminalidad}

Proponemos escribir una nueva historia entre teatro, drama y liminalidad. Observemos la posibilidad de esa historia poniendo las nociones de teatro-matriz, liminalidad, imaginística corporal y dramático / no-dramático en relación con las prácticas artísticas del mundo antiguo. ${ }^{18}$ En este período no existe el drama absoluto (identificado por Szondi con el teatro moderno), en la Antigüedad clásica el teatro es el imperio de la liminalidad. Entendemos por dramática toda acción corporal imaginística, completa o fragmentaria (justamente porque hablamos de liminalidad), que va asimilada o acompañada a componentes no-dramáticos.

Creemos que, en consecuencia, no es pertinente, si de fenómenos de la liminalidad se trata, reducir el corpus a los consabidos "subgéneros teatrales": comedia, tragedia, drama

\footnotetext{
18 Para ampliar estas observaciones, remitimos a nuestra conferencia en el marco de las I Jornadas "(En)clave teatral: reflexiones sobre el drama en el mundo antiguo. Tema 2015: El personaje" (Universidad de Buenos Aires, Facultad de Filosofía y Letras, Instituto de Filología Clásica, 2015b).
} 
satírico, mimo. Partamos de la pregunta por el corpus: abarcaría todas aquellas prácticas en las que identifiquemos convivio + poíesis corporal + expectación. En tanto formas dramáticas pre-modernas, los sub-géneros teatrales: la tragedia, la comedia, el drama satírico y el mimo ya son en sí mismas prácticas de la liminalidad teatral. Pero, además, en tanto formas conviviales, poiético-corporales y expectatoriales, las prácticas de la literatura oral (la épica, la lírica) también pueden ser pensadas desde la liminalidad teatral (Florence Dupont, La invención de la literatura). ¿Cómo se interpreta corporalmente la épica y la lírica? Podemos imaginar que Homero "actúa" voces, personajes, situaciones de manera fragmentaria (es decir, en liminalidad con fragmentos no -actuados). Podemos asimilarlas, desde esta perspectiva, a dos formas de teatro liminal (de acuerdo con la fórmula [teatro + de...]: el teatro del relato y el teatro de la poesía. El corpus de la teatralidad liminal se ampliaría con la danza y la música: teatro de la danza y teatro de la música. Debemos poner en conexión este conjunto de prácticas de la liminalidad teatral.

¿Dónde está presente la liminalidad en las formas consideradas tradicionalmente teatrales: la tragedia, la comedia, el drama satírico, el mimo? En principio reconocemos su condición fronteriza en varios aspectos:

- la relación con el rito

- la relación con las otras artes (la danza, la música, el espacio arquitectónico, la plástica, la escultura)

- la relación con las diferentes formas de teatralidad social y la transteatralización.

Recordemos las relaciones que Aristóteles establece en Retórica entre el político, el poeta y el actor. Recordemos además el vínculo entre teatro y retórica estudiado, entre otros, por
Aldo Pricco, como de "sostener la inquietud", de seducir, de organizar la mirada.

En cuanto a la inmanencia de cada una de estas poéticas, a los campos procedimentales y a su uso, reconocemos la liminalidad otra vez en diversos aspectos:

- sin duda en la estructura de los prólogos, coros y epílogos (como ya señala Szondi para diferenciar el drama antiguo del drama absoluto de la Modernidad), por su condición no dialógica (el diálogo entre personajes sería, para Szondi, la forma principal del drama absoluto):

- pero también en el diálogo, por ejemplo, en la comedia de Aristófanes, en los procedimientos que incluyen la enunciación como enunciado (ejemplo: las numerosas autorreferencias metateatrales);

- también en implícitos procedimientos de actuación desde la enunciación (acción física o físico-verbal) de los textos dramáticos, por ejemplo, el salirse del personaje gestualmente o en la forma de enunciar verbalmente, mecanismos que plantean la disyunción entre actor y personaje (Szondi, p. 20).

- también reconocemos en el teatro una dimensión no-representativa imaginística, puramente musical, rítmica, de intensidades y velocidades corporales, o puramente laboral (técnica, de ordenamiento de la escena, retirar objetos, cambiar un telón o un accesorio de lugar, etc.) no integrado a lo representacional dramático.

Creemos que es fundamental observar los mecanismos de liminalidad en cada subgénero teatral y confrontarlos en el eje sincrónico: son diferentes en la tragedia y en la comedia, en el drama satírico y en el mimo.

También es fundamental proyectar tanto las continuidades y cambios de cada sub-género y de los sub-géneros entre sí en el eje 
diacrónico. La historia del teatro como sucesión de combinatorias de dramático / no-dramático.

La liminalidad debe ser considerada, además, desde las formas de producción en relación con la escena: si se trata de una dramaturgia pre-escénica o de una dramaturgia escénica y post-escénica (a tal vez pre-escénica de segundo grado). ${ }^{19}$ Se trata de comprender si la producción era transitiva, "puesta", en el sentido de poner en escena un texto escrito previamente, o escritura escénica en el convivio. La pregunta se relaciona también con el estatus pre-escénico (de primero o de segundo grado) o post-escénico de los textos conservados: si son textos homoestructurados (por la experiencia de la escritura al margen de/anterior a la escena) o heteroestructurados (atravesados por la experiencia de la literaturidad y la teatralidad).

Todos estos aspectos afectan a la consideración del personaje, ya sea por las diferencias de la liminalidad en los diversos sub-géneros, por la comunicación con las otras artes, por la relación con el rito o la teatralidad social, por la relación entre actor y personaje, por el hecho de que los parlamentos sean escritos a priori o a posteriori de la experiencia escénica, ya sea porque los parlamentos se relacionan en el acontecimiento con una determinada enunciación corporal no inscripta en la letra.

Sabemos que muchos de estos aspectos han sido estudiados total o parcialmente; sabemos también que este programa contribuirá a reordenar lo ya conocido y a detectar vacancias.

En conclusión, debemos escribir una nueva historia de las relaciones entre teatro, drama y liminalidad a través de los siglos. Hay cruce de dramático y no-dramático en toda la historia de las manifestaciones del teatro-matriz. $Y$ este es el programa de investigación que proponemos, valiéndonos de las nociones de teatro-matriz, liminalidad e imaginística corporal en relación con las prácticas artísticas desde el mundo antiguo hasta el presente.

Bibliografía

ARISTÓTELES. El arte de la Retórica. Buenos Aires: Eudeba, 2010.

ARISTÓTELES. Poética. Traducción, notas e introducción de Eduardo Sinnott. Buenos Aires: Colihue Clásica, 2011.

ARTAUD, Antonin. "Théâtre Alfred Jarry. Saison 1928". En: ARTAUD, Antonin, Oeuvres complètes II. Paris: Gallimard, 1970, 34-39. La traducción es nuestra.

ARTAUD, Antonin. El teatro y su doble. Barcelona: Edhasa, 1996. Traducción de Enrique Alonso y Francisco Abelenda.

AUDIVERT, Pompeyo. "Identidad sagrada". En Página/12, 30 de diciembre de 2014, 31, Sección "Opinión".

BOAL, Augusto. Teatro del Oprimido. Buenos Aires: InterZona, 2015.

DIEGUEZ, Ileana. Escenarios liminales. Teatralidades, performances y política. Buenos Aires, Atuel, 2007.

${ }^{19}$ Sobre estas distinciones, remitimos a Dubatti, 2013b. 
DIEGUEZ, Ileana. Escenarios liminales. Teatralidades, performatividades, políticas. México, Paso de Gato, 2014. Edición revisada y aumentada.

DUBATTI, Jorge. Poéticas y política en el teatro de Eduardo Pavlovsky (1960-2003). Tesis doctoral presentada en la Universidad de Buenos Aires, 2004.

DUBATTI, Jorge. Filosofía del Teatro I. Convivio, experiencia, subjetividad. Buenos Aires: Atuel, 2007.

DUBATTI, Jorge. Concepciones de teatro. Poéticas teatrales y bases epistemológicas. Buenos Aires: Colihue Universidad, 2009.

DUBATTI, Jorge. Filosofía del Teatro II. Cuerpo poético y función ontológica. Buenos Aires: Atuel, 2010.

DUBATTI, Jorge. "El teatro de la vanguardia histórica: futurismo, dadaísmo, surrealismo. Poética Comparada y propuesta de tres modalidades de análisis". Actas del III Congreso Internacional de Artes en Cruce. Buenos Aires: Universidad de Buenos Aires, Carrera de Artes, Departamento de Artes, 2013a.

DUBATTI, Jorge. "Filosofía del Teatro, acontecimiento teatral: cambios en los conceptos de drama, dramaturgia, texto dramático, poética dramática y notación dramática”, en Cristian Figueroa Acevedo y Astrid Quintana Fuentealba, compiladores, V Congreso Internacional de Dramaturgia Hispanoamericana Actual, Valparaíso, Chile, Universidad de Valparaíso, Facultad de Arquitectura, Carrera de Teatro, 2013b, 31-66.
DUBATTI, Jorge. "Coordenadas para el estudio del teatro en la Edad Media: unidad historiográfica, pertinencia epistemológica, periodización y pensamiento antiteatral". La revista del CCC [en línea]. Enero / Abril 2013c, n 17. [citado 2013-05-19]. Disponible en Internet: http://www.centrocultural.coop/revista/articulo/383/.

DUBATTI, Jorge. Filosofía del Teatro III. El teatro de los muertos. Buenos Aires: Atuel, 2014a.

DUBATTI, Jorge. El teatro de los muertos. Filosofía del teatro y epistemología de las ciencias del teatro. México: Libros de Godot, 2014b.

DUBATTI, Jorge. "Teatralidad, teatro, transteatralización: notas sobre teatro argentino actual (y en particular sobre La máquina idiota de Ricardo Bartís)", Karpa (Dissident Theatricalities, Visual Arts and Culture) (Teatralidades disidentes, artes visuales y cultura), College of Arts and Letters (California State University, Los Angeles). Número 7 (2014c). "Performance y teatralidades en Argentina". Online Journal. English-Español-Portugués.

DUBATTI, Jorge. "La escena teatral argentina en el siglo XXI. Permanencia, transformaciones, intensificaciones, aperturas", en Luis Alberto Quevedo, compilador, La cultura argentina hoy. Tendencias!, Buenos Aires, Siglo Veintiuno Editores y Fundación OSDE, 2015a, 151-196.

DUBATTI, Jorge. "Dramático y no-dramático. Poéticas de la liminalidad en el drama antiguo". En: Actas I Jornadas "(En)clave teatral: reflexiones sobre el drama en el mundo antiguo. Tema 2015: El personaje", Universidad de 
Buenos Aires, Facultad de Filosofía y Letras, Instituto de Filología Clásica, 2015b.

DUBATTI, Jorge. "Proyecciones de la poética de la vanguardia teatral histórica (1896-1939) y de la postvanguardia en la dramaturgia de Alejandro Finzi", en Margarita Garrido, dir., VI Jornadas de las Dramaturgias de la Norpatagonia Argentina: Neuquén, Universidad Nacional del Comahue, EDUCO Editorial Universitaria, 2015c, 29-42.

DUBATTI, Jorge, comp. Dramático y no-dramático. Poéticas de liminalidad en el teatro. México: Paso de Gato, 2016a (en prensa).

DUBATTi, Jorge. "El teatro como observatorio ontológico en las poéticas de la Postdictadura: concepciones y pluralismo", en Nuevas orientaciones en Teoría y Análisis Teatral. Homenaje a Patricio Esteve, Jorge Dubatti coord., Bahía Blanca, Editorial de la Universidad Nacional del Sur, EDIUNS, Serie Extensión, Colección Estudios Sociales y Humanidades, 2016b, 203-255.

DUPONT, Florence. L'Invention de la Littérature. De l'ivresse grecque au livre latin. Paris: La Découverte, 1994.

DUPONT, Florence. Aristote ou le vampire $d u$ théâtre occidental. Paris: Aubier, 2007.

GASSNER, John. The Theatre in Our Times. New York: Crowner Publishers Inc., 1963.

GEIROLA, Gustavo. Teatralidad y experiencia política en América Latina. Irvine: Ediciones Gestos, 2000.

HEGEL, G. W. F. Estética. Traducción de Hermenegildo Giner de los Ríos. Buenos Aires:
Losada, 2008, tomo II.

KAISER, Wolfgang. Interpretación y análisis de la obra literaria. Madrid: Gredos, 1968.

LEHMANN, Hans-Thies. Teatro posdramático. México-Murcia: Paso de Gato / CENDEAC, 2013.

LOTMAN, Jurij. Estructura del texto artístico. Madrid, Istmo, 1988.

LOTMAN, Jurij. La semiosfera I. Semiótica de la cultura y del texto. Madrid, Cátedra, 1996.

MANDOKI, Katya. Estética cotidiana y juegos de la cultura. Prosaica uno. México, Siglo XXI Editores, 2006a.

MANDOKI, Katya. Prácticas estéticas e identidades sociales. Prosaica dos. México, Siglo XXI Editores, 2006b.

MANDOKI, Katya. La construcción estética del Estado y de la identidad nacional. Prosaica tres. México, Siglo XXI Editores, 2007.

NAUGRETTE, Catherine. Estética del Teatro. Buenos Aires, Ediciones Artes del Sur, 2004.

PRICCO, Aldo Rubén. Sostener la inquietud. Buenos Aires-Rosario: Universidad Nacional de Rosario y Biblos, 2015.

PRIETO STAMBAUGH, Antonio. "iLucha libre! Actuaciones de teatralidad y performance". En Domingo Adame coord./ed., Actualidad de las Artes Escénicas. Perspectiva latinoamericana, Universidad Veracruzana, Facultad de Teatro, Xalapa, México, 2009, 116-143. 
RIZK, Beatriz J. Posmodernismo y teatro en América Latina: teorías y prácticas en el umbral del siglo XXI. Madrid: Iberoamericana, 2001. Segunda edición: Lima / Minneapolis: Iberoamerican Theatre, University of Minnesota / Universidad de San Marcos, 2007.

ROZIK, Eli. Las raíces del teatro. Repensando el ritual y otras teorías del origen. Buenos Aires: Colihue, 2014a.

ROZIK, Eli. Theatre Sciences: a Plea for a Multidisciplinary Approach to Theatre Studies. London: Sussex Academic Press, 2014b.

SÁNCHEZ, José A. Prácticas de lo real en la escena contemporánea. México, Paso de Gato, 2013.

SASSONE, Ricardo, "Inscripción de la escena teatral en el contexto de la escena 'neotecnológica', ADE Teatro, n. 106 (julio-setiembre 2005), 49-59.

SCHECHNER, Richard. Performance. Buenos Aires: Universidad de Buenos Aires, Libros del Rojas, 2000.

SCHECHNER, Richard. Estudios de la representación. Una introducción. México, FCE, 2012.

STAIGER, Emil. Conceptos fundamentales de poética. Madrid, Rialp, 1966.

SZONDI, Peter. Teoría del drama moderno (1880-1950). Tentativa sobre lo trágico. Barcelona: Destino, 1994.

SZONDI, Peter. El drama burgués. Prólogo de
J. Dubatti. Buenos Aires: Prometeo, 2015. (en prensa).

TELLAS, Vivi, entrevista en la Escuela de Espectadores de Buenos Aires realizada por Jorge Dubatti, 2010.

Recebido em 13/05/2015 Aprovado em 18/06/2016 